\title{
CAMBridge
}

OUTSTANDING INTERNATIONAL LEGAL MATERIALS from

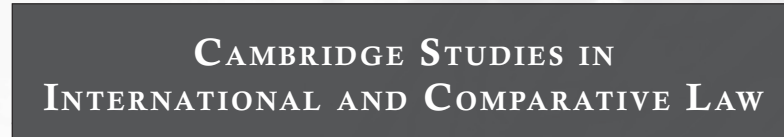

International Law and the Arctic

Michael Byers

\$99.00: Hardback:

978-1-107-04275-9: 337 pp.

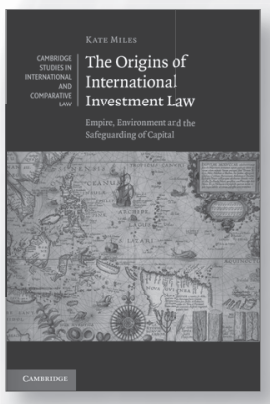

The Origins of International Investment Law

Empire, Environment and the Safeguarding of Capital

Kate Miles

$\$ 120.00:$ Hardback:

978-1-107-03939-1: $495 \mathrm{pp}$

New in Paperback!

Legal Personality in International Law

Roland Portmann \$39.99: Paperback:

978-1-107-62778-9: 362 pp.
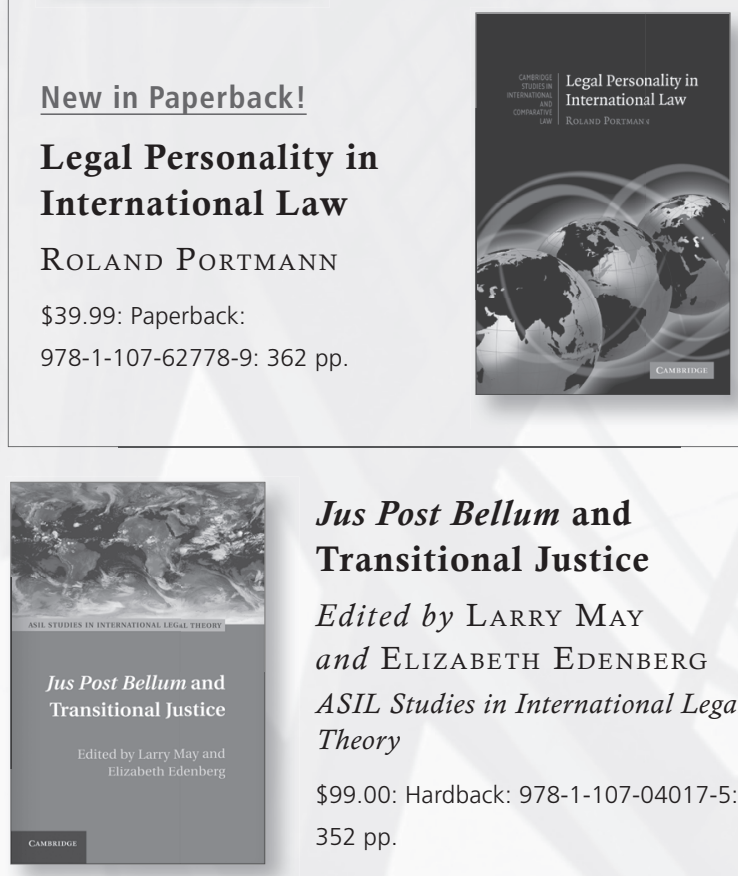

Jus Post Bellum and

Transitional Justice

Edited by LARRY MAY and Elizabeth Edenberg ASIL Studies in International Legal Theory

\$99.00: Hardback: 978-1-107-04017-5: $352 \mathrm{pp}$.

Prices subject to change.

\section{Christian Law}

Contemporary Principles

Norman Doe

\$115.00: Hardback: 978-1-107-00692-8: $448 \mathrm{pp}$.
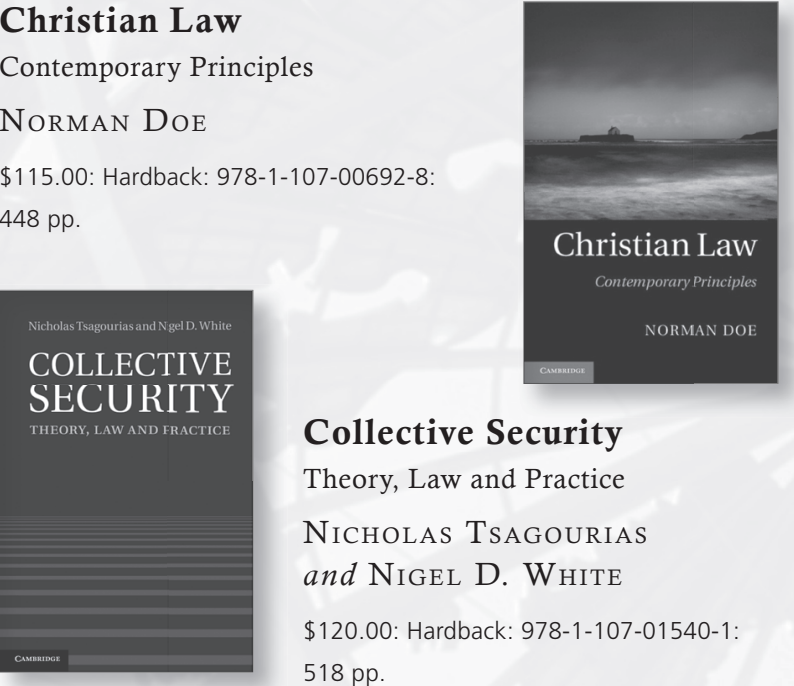

\section{Collective Security}

Theory, Law and Practice

Nicholas Tsagourias and Nigel D. White

\$120.00: Hardback: 978-1-107-01540-1: $518 \mathrm{pp}$.

New in Paperback!

Forging a Convention for Crimes against Humanity Edited by Leila Nadya Sadat \$45.00: Paperback: 978-1-107-67679-4: $593 \mathrm{pp}$.

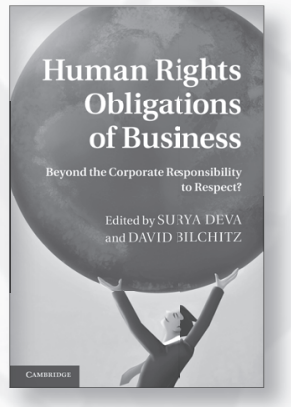

Human Rights Obligations of Business

Beyond the Corporate Responsibility to Respect?

Edited by Surya DEva and DAviD BILChITZ

\$130.00: Hardback: 978-1-107-03687-1: $452 \mathrm{pp}$.

Human Rights under State-Enforced Religious Family Laws in Israel, Egypt and India

YÜKSel Sezgin

Cambridge Studies in Law and Society \$99.00: Hardback: 978-1-107-04140-0 $319 \mathrm{pp}$

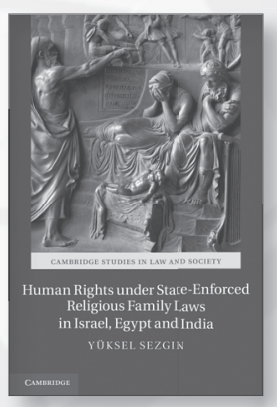

www.cambridge.org/law @CambUP_Law 


\section{CAMbridge}

OUTSTANDING INTERNATIONAL LEGAL MATERIALS from CAMBRIDGE UNIVERSITY PRESS

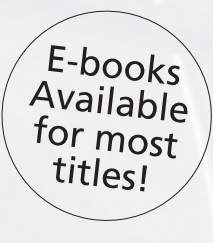

\section{Cambridge Studies in LAW AND Society}

\section{Complementarity} in the Line of Fire

The Catalysing Effect of the International Criminal Court in Uganda and Sudan

Sarah M. H. Nouwen

$\$ 110.00$ : Hardback

978-1-107-01078-9: 524 pp.

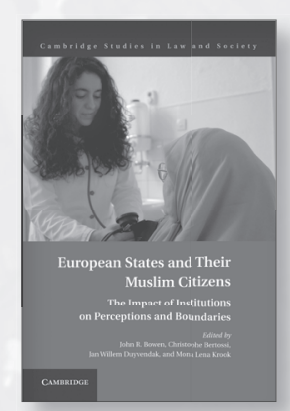

\section{European States}

and their

\section{Muslim Citizens}

The Impact of Institutions on Perceptions and Boundaries

Edited by JOHN R. BOWEN, Christophe Bertossi, Jan Willem Duyvendak, and Mona Lena Krook \$95.00: Hardback: 978-1-107-03864-6: $288 \mathrm{pp}$

\section{Political and}

Legal Transformations of an Indonesian Polity

The Nagari from Colonisation to Decentralisation

FRANZ VON

BEnda-BeCKMANN and KEEBET VON

BENDA-BECKMANN

\$120.00: Hardback:

978-1-107-03859-2: 525 pp.

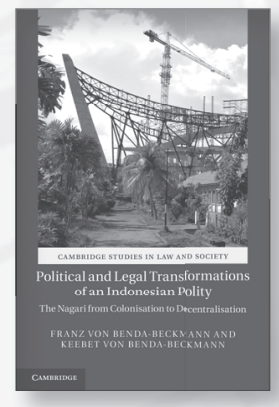

\section{Legal Emblems and the Art of Law}

Obiter Depicta as the Vision of Governance

Peter Goodrich

\$99.00: Hardback: 978-1-107-03599-7: $288 \mathrm{pp}$.
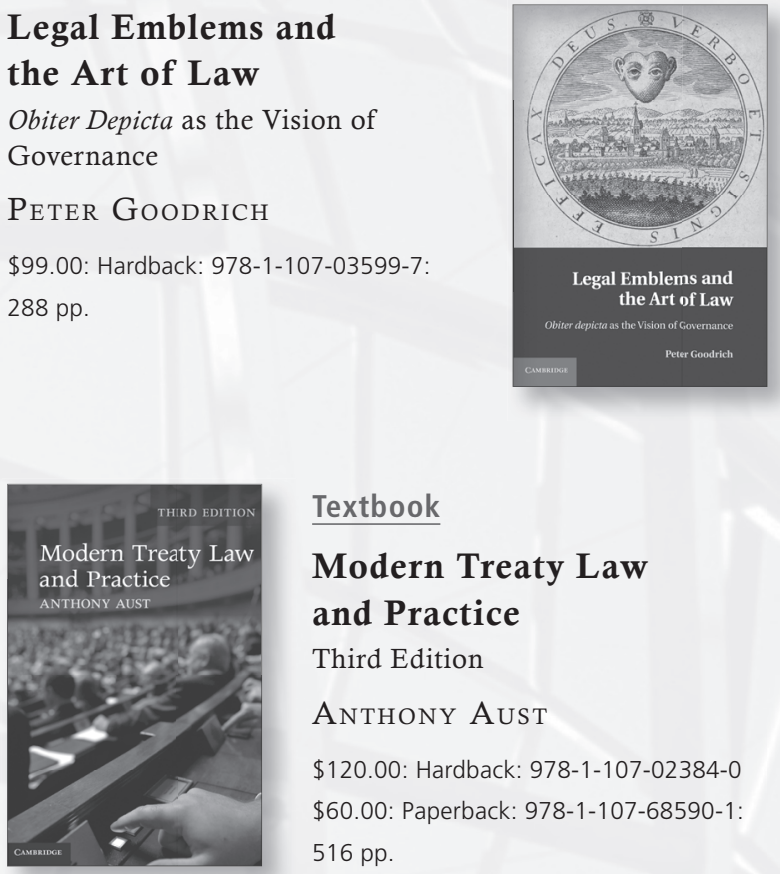

Textbook

Modern Treaty Law and Practice

Third Edition

Anthony Aust

\$120.00: Hardback: 978-1-107-02384-0 $\$ 60.00$ : Paperback: 978-1-107-68590-1 $516 \mathrm{pp}$.

Nationalism and the

Rule of Law

Lessons from the Balkans and Beyond

IAVOR RANGELOV

\$95.00: Hardback: 978-1-107-01219-6: $240 \mathrm{pp}$.
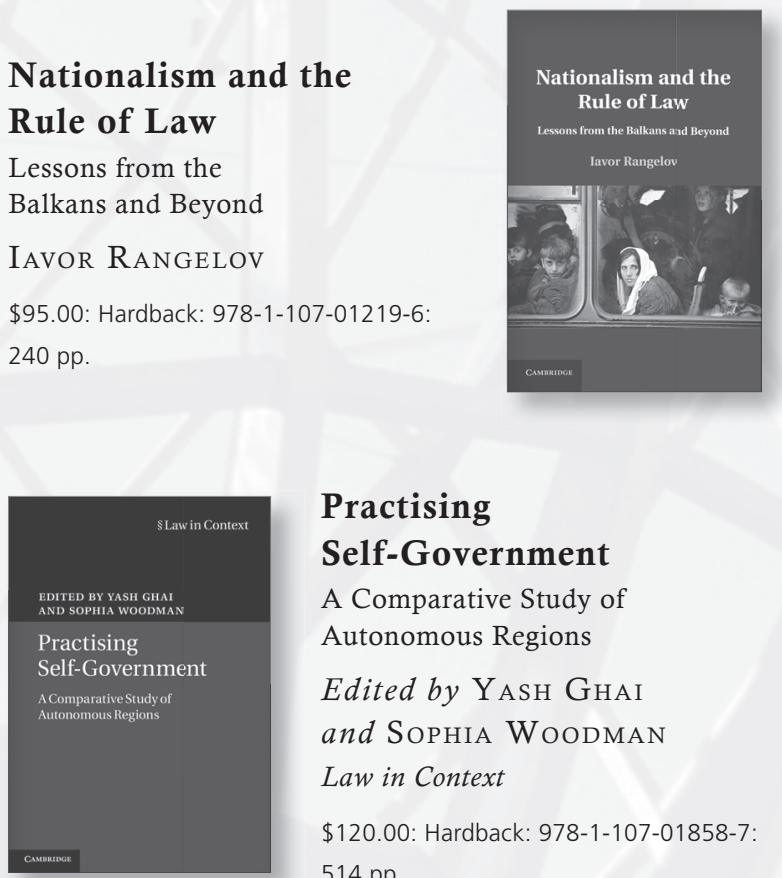

Practising Self-Government

A Comparative Study of Autonomous Regions

Edited by Yash GHAI and SOPHIA WoOdMAN Law in Context

\$120.00: Hardback: 978-1-107-01858-7: $514 \mathrm{pp}$

Prices subject to change. 


\section{CAMBRIDGE}

OUTSTANDING INTERNATIONAL LEGAL MATERIALS from CAMBRIDGE UNIVERSITY PRESS

\section{Risk Governance} of Offshore Oil and Gas Operations

Edited by PREBEN Lindøe, Michael Baram, and ORTWIN RENN

\$115.00: Hardback: 978-1-107-02554-7: $450 \mathrm{pp}$.
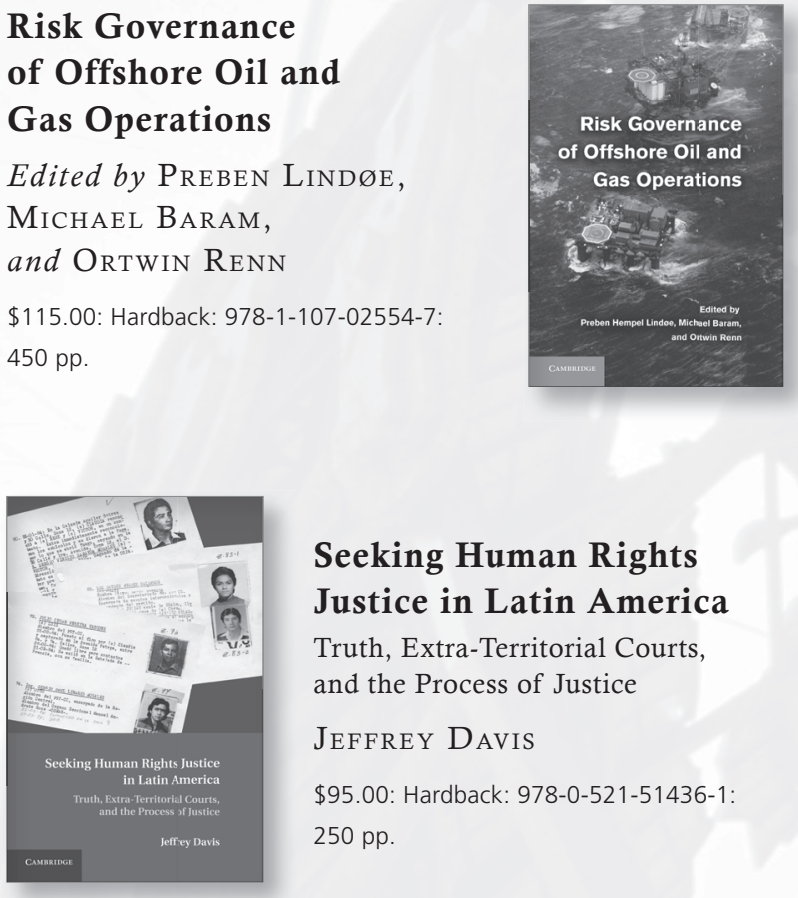

Seeking Human Rights Justice in Latin America Truth, Extra-Territorial Courts, and the Process of Justice

JEFFREY DAVIS

\$95.00: Hardback: 978-0-521-51436-1 $250 \mathrm{pp}$.

\section{Social and Political}

Foundations of

Constitutions

Edited by Denis J. Galligan and Mila Versteeg

Comparative Constitutional Law and Policy

\$160.00: Hardback: 978-1-107-03288-0: $696 \mathrm{pp}$.
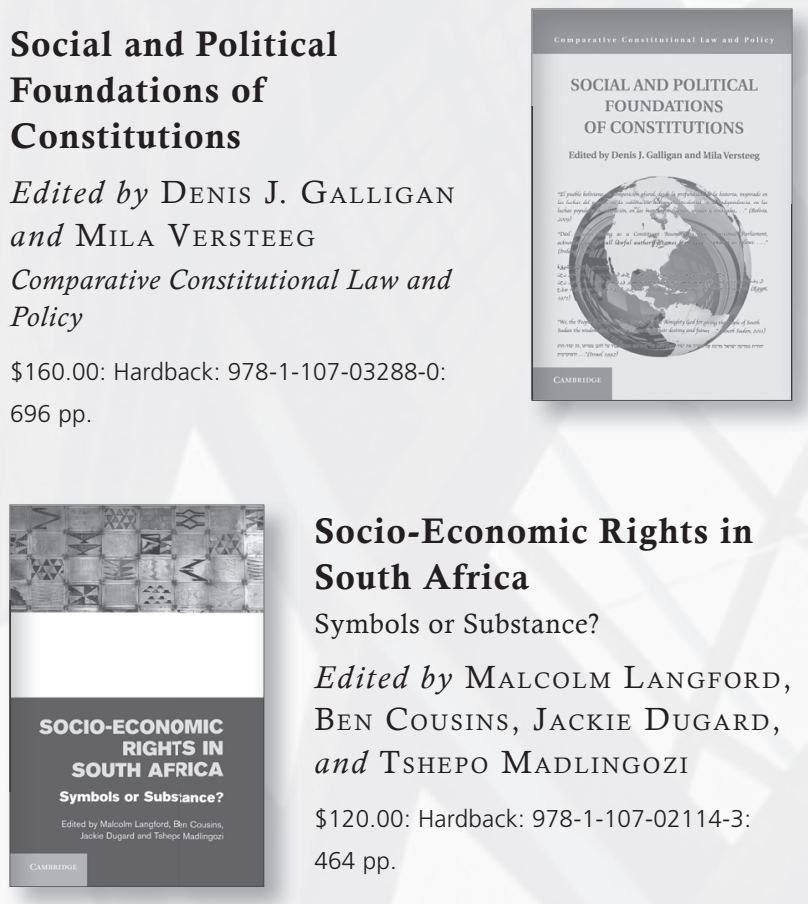

Socio-Economic Rights in South Africa

Symbols or Substance?

Edited by MALCOLM LANGFORD, Ben Cousins, Jackie Dugard, and Tshepo MAdLingozi

\$120.00: Hardback: 978-1-107-02114-3: $464 \mathrm{pp}$.

\section{Teaching Law}

Justice, Politics, and the

Demands of Professionalism

Robin L. West

\$90.00: Hardback: 978-1-107-04453-1

\$32.99: Paperback: 978-1-107-67819-4: $256 \mathrm{pp}$.
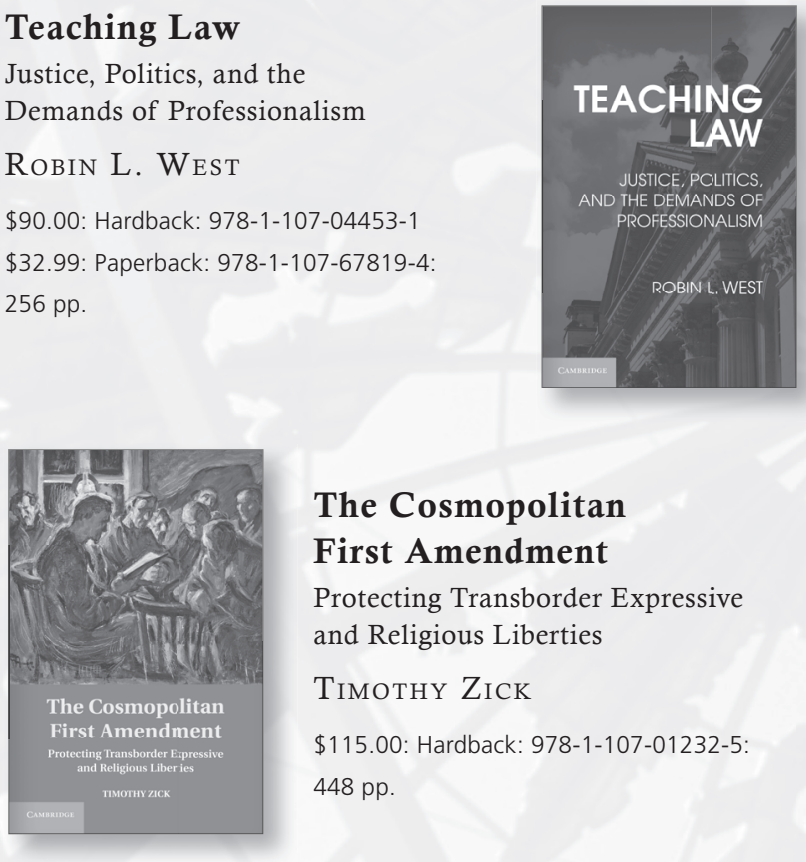

\section{The Cosmopolitan}

\section{First Amendment}

Protecting Transborder Expressive and Religious Liberties

\section{Tiмотнy Zick}

\$115.00: Hardback: 978-1-107-01232-5: $448 \mathrm{pp}$

\section{The European Union's}

Shaping of the

International

Legal Order

Dimitry Kochenov

and Fabian Amtenbrink

\$110.00: Hardback: 978-1-107-03333-7:

$416 \mathrm{pp}$
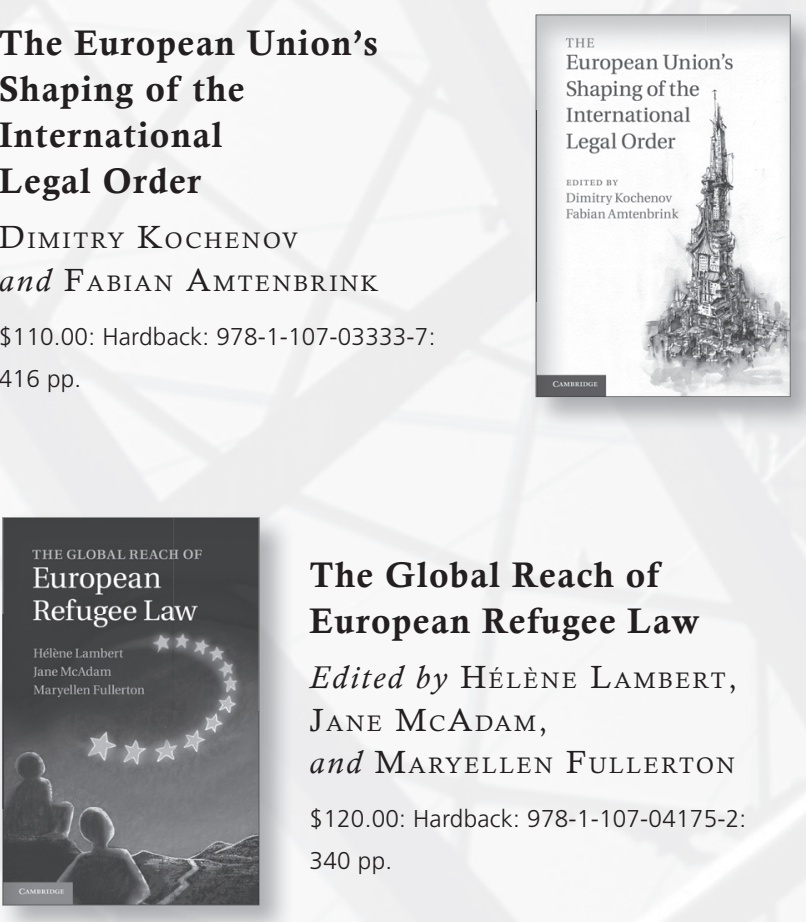

The Global Reach of European Refugee Law

Edited by Hélène Lambert, Jane McAdam, and Maryellen Fullerton \$120.00: Hardback: 978-1-107-04175-2: $340 \mathrm{pp}$. 


\section{CAMBRIDGE}

OUTSTANDING INTERNATIONAL LEGAL MATERIALS from CAMBRIDGE UNIVERSITY PRESS

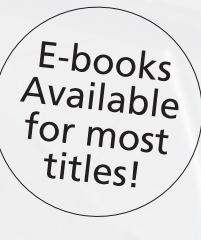

Textbook

The Law and Policy of the World Trade Organization Text Cases and Materials Third Edition

Peter Van den Bossche and WERNER ZDOUC

\$150.00: Hardback: 978-1-107-02449-6 \$75.00: Paperback: 978-1-107-69429-3: $1,100 \mathrm{pp}$.

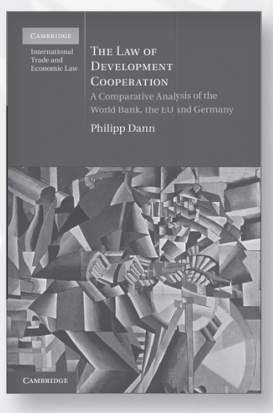

The Law of Development Cooperation

A Comparative Analysis of the World Bank, the EU and Germany

\section{Philipp DANN}

Translated by Andrew Hammel Cambridge International Trade and Economic Law

\$130.00: Hardback: 978-1-107-02029-0: $604 \mathrm{pp}$.

The Legitimacy of International Human Rights Regimes Legal, Political and Philosophical Perspectives

Edited by Andreas Føllesdal, Johan KarLSSON SchafFER, and Geir Ulfstein

Studies on Human Rights Conventions

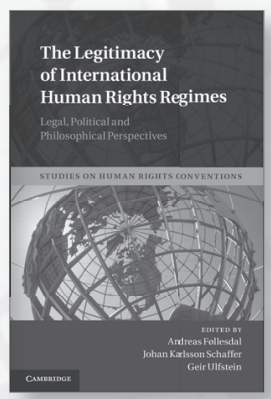

\$99.00: Hardback: 978-1-107-03460-0: $319 \mathrm{pp}$.

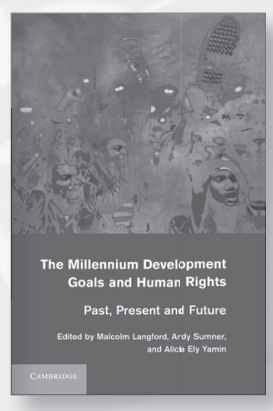

The Millennium

Development Goals and Human Rights

Past, Present and Future

Edited by Malcolm Langford, Andy Sumner, and Alicia Ely Yamin

\$140.00: Hardback: 978-1-107-03191-3: $571 \mathrm{pp}$
The UNHCR

and the Supervision of International Refugee Law

Edited by James C. Simeon

\$115.00: Hardback: 978-1-107-02285-0: $384 \mathrm{pp}$.
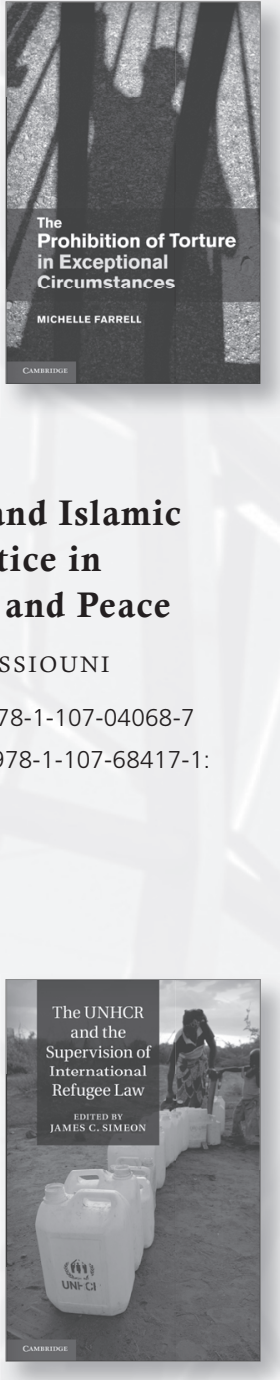

The Shari'a and Islamic Criminal Justice in Time of War and Peace

M. Cherif Bassiouni

\$95.00: Hardback: 978-1-107-04068-7 \$34.99: Paperback: 978-1-107-68417-1 $416 \mathrm{pp}$

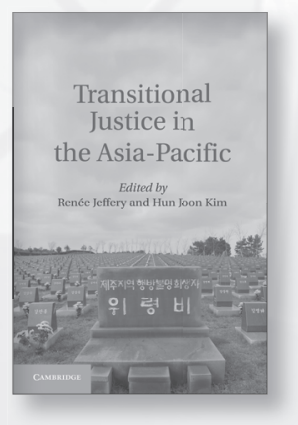

Transitional Justice in the Asia-Pacific

Edited by ReneE JefFery and HuN JoON KIM

\$99.00: Hardback: 978-1-107-04037-3: $312 \mathrm{pp}$

Prices subject to change. 


\section{International Law from Hart Publishing}

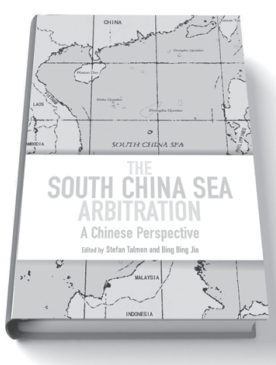

\section{The South China Sea \\ Arbitration}

A Chinese Perspective

Edited by Stefan Talmon and Bing Bing Jia

On 22 January 2013, the Republic of the Philippines instituted arbitral proceedings against the People's Republic of China ('PRC') under the United Nations Convention on the Law of the Sea ('UNCLOS') with regard to disputes between the two countries in the South China Sea ('South China Sea Arbitration'). On 19 February 2013, the PRC formally expressed its opposition to the institution of proceedings, making it clear from the outset that it will not have any part in these arbitral proceedings and that this position will not change. It is thus to be expected that over the next year and a half, the tribunal will receive written memorials and hear oral submissions by the Philippines only. The Chinese position will go unheard. However, the tribunal is under an obligation, before making its award, to satisfy itself not only that it has jurisdiction over the dispute but also that the claims brought by the Philippines are well founded in fact and law (UNCLOS Annex VII, Art. 9). The book aims to offer a (not the) Chinese perspective on some of the issues to be decided by the tribunal and thus to assist the tribunal in meeting its obligations under the Convention. The book does not set out the official position of the Chinese government but is rather to serve as a kind of amicus curiae brief advancing possible legal arguments on behalf of the absent respondent

Stefan Talmon is Professor of Public Law, Public International Law and European Union Law, and Director of the Institute for Public International Law at the University of Bonn. Bing Bing Jia, D. Phil. (Oxon.) is Professor of International Law, Law School, Tsinghua University, Beijing. He also acts as a consultant on matters of international law.

$$
\text { Jan 20I4 246pp Hbk 978I849465472 RSP: } € 30 / \text { US } \$ 60
$$

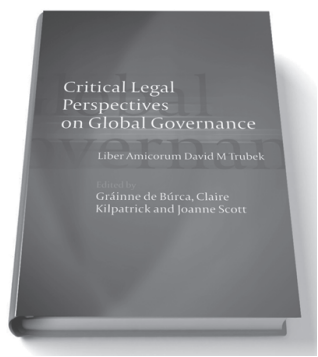

\section{Critical Legal Perspectives} on Global Governance Liber Amicorum David M Trubek Edited by Gráinne de Búrca, Claire Kilpatrick and Joanne Scott

This book of essays, written in honour of Professor David Trubek, explores many of the themes which he has himself written about, most notably the emergence of a global critical discourse on law and its application to global governance. As law becomes ever more implicated in global governance and as processes related to and driven by globalisation transform legal systems at all levels, it is important that critical traditions in law adapt to the changing legal order and problématique. This book brings together critical scholars from the EU, and North and South America to explore the forms of law that are emerging in the global governance context, the processes and legal roles that have developed, and the critical discourses that have been formed.

Gráinne de Búrca is Florence Ellinwood Allen Professor of Law at NYU Law School. Claire Kilpatrick is Professor of International and European Labour and Social Law at the European University Institute. Joanne Scott is Professor of European Law at University College London.

Dec 2013 460pp Hbk 978I849464I92 RSP: $£ 55$ / US\$II0

\section{NEW JOURNAL IN 2014 \\ Journal on the Use of Force and International Law}

(including the Digest of State Practice on the Use of Force)

Editors-in-Chief

Dr James A. Green (University of Reading)

Dr Christian Henderson (University of Liverpool)

Dr Tom Ruys (Leuven Centre for Global Governance Studies)

Book Review Editor

Dr Francis Grimal (University of Buckingham)

The Journal on the Use of Force and International Law (JUFIL) is a new peer-reviewed journal covering all aspects of the law governing the use of force (jus ad bellum), as distinct from other areas of international law relating to security issues, such as International Humanitarian Law or International Criminal Law. In addition to publishing research of the highest quality and impact, of both a theoretical and more practical nature, the Journal will support the conducting of research, through a digest of state practice on the use of force - a relatively unique feature for an international law journal - which will act as a key means of assessing the development of customary international law in the area. JUFIL is expected to attract contributions both from scholars writing on the general nature of the law in the area of jus ad bellum and those examining particular uses of force or developments in this field of law. All submissions will be double-blind peer reviewed. Please visit the Hart Publishing website for further details including information about the International Advisory Board and the Editorial Board.

Vol I, 2014 (2 issues)

Print ISSN: 2053-I702 / Online ISSN: 2053-I7I0 www.hartjournals.co.uk/jufil

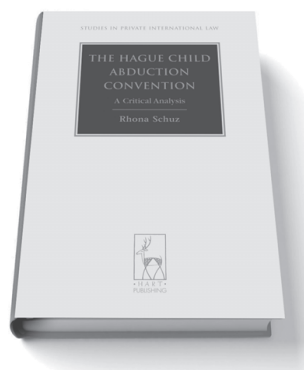

The Hague Child Abduction Convention

A Critical Analysis Rhona Schuz

From the Foreword by

Brenda Hale, Justice of the Supreme Court of the United Kingdom

... a study which deserves to be read by anyone with an interest in the modern phenomenon of international child abduction, whether judge, practitioner, policy-maker, parent, researcher or scholar. There is plenty for us all to think about.'

This book provides an up-to-date, clear and highly readable discussion of the international operation of the Abduction Convention, together with in-depth critical academic analysis in light of the objectives of the Convention and other relevant legal norms, such as the 1989 United Nations Convention on the Rights of the Child. Throughout the book, examples are brought from case law in many jurisdictions and reference is made to relevant legal and social science literature and empirical research.

Rhona Schuz is a Senior Lecturer and Director of the Centre for the Rights of the Child and the Family at Sha'arei Mishpat Law School, Israel (formerly lecturer at the London School of Economics).

Nov 2013 476pp Hbk 9781849460170 RSP: $£ 70 /$ US $\$ 140$

Published by Hart Publishing, Oxford, UK US Distributors: ISBS, 920 NE 58th Ave, Suite 300, Portland, OR, 972I3-3786, USA

Tel + I 503287 3093; Fax + I 503280883 E-mail orders@isbs.com; Website www.hartpub.co.uk

Hart Publishing Ltd. is registered in England No. 3307205

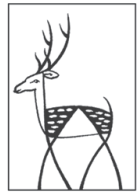




\section{NTERNATIONAL LAW: 100 WAYS IT SHAPES OUR LIVES}

Many find international law abstract and static. Topics such as war and peace or relationships between countries are considered by some to be not so much questions of law, but of power and influence. Others question the existence of international law.

International Law: 100 Ways It Shapes Our Lives was conceived from the proposition that international law not only exists, but also penetrates more deeply and broadly into everyday life than is generally recognized. Some ways are of relatively recent vintage, while others are long-standing. 100 examples were identified by ASIL members, vetted by a smaller group of experts, and organized into seven chapters: 1) daily life; 2) leisure; 3) travel; 4) commerce 5) health and the environment; 6) personal liberty; 7 ) public safety and global security.

Join us in demonstrating how international law shapes our lives by

- Visiting 100 Ways at http://www.asil100.org/ways.html;

- Using it in teaching and general civic education programs;

- Adding ways to the list; and

- Sharing your experiences using International Law: 100 Ways It Shapes Our Lives.

We hope that this creative and interactive project will help demonstrate the diversity and the centrality of international law to our lives today.
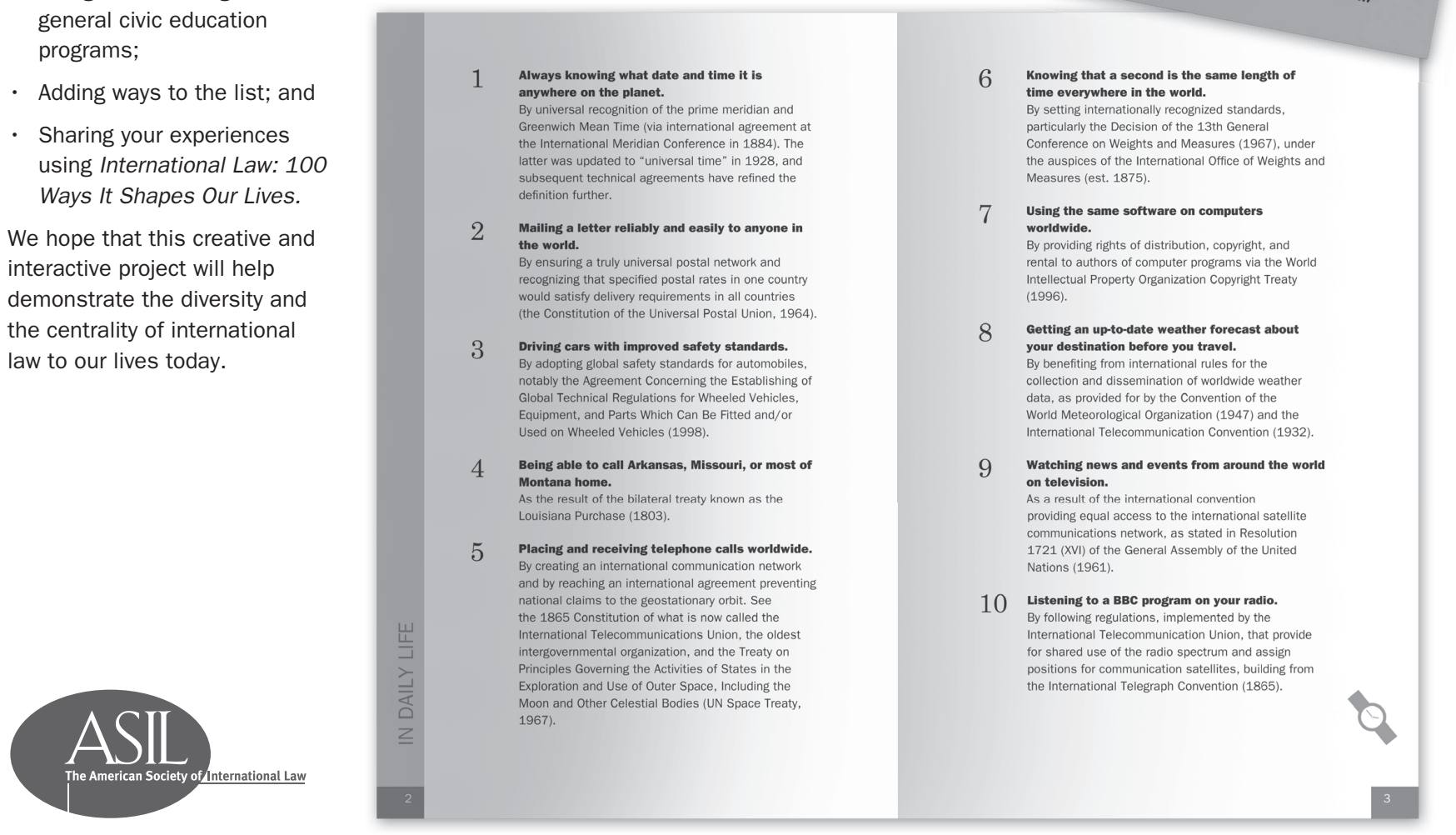

w w w. a s i I 100 . org 


\section{(11) American Society of International Law \\ Howard M. Holtzmann Research Center for the Study of International Arbitration and Conciliation}

T he Howard M. Holtzmann Research Center for the Study of International Arbitration and Conciliation was established by the American Society of International (ASIL) to serve as an education and research forum for individuals interested in international dispute resolution. Building on the Society's recognized expertise in this growing field, the Center will serve as an indispensable research and education resource, providing cutting-edge, expert information and analysis on significant issues and current developments in the international arbitration field. Center activities will include:

- Collection of research materials on international arbitration, including Judge Holtzmann's personal library and papers;

- A regular program of events, including a speaker series with leading figures and continuing legal education courses on hot topics in the field; and

- Working groups and task forces convened to address the key challenges and emerging issues relating to international arbitration.

The Center is conveniently located at the Society's headquarters and is open to everyone interested in learning more about international arbitration and conciliation.

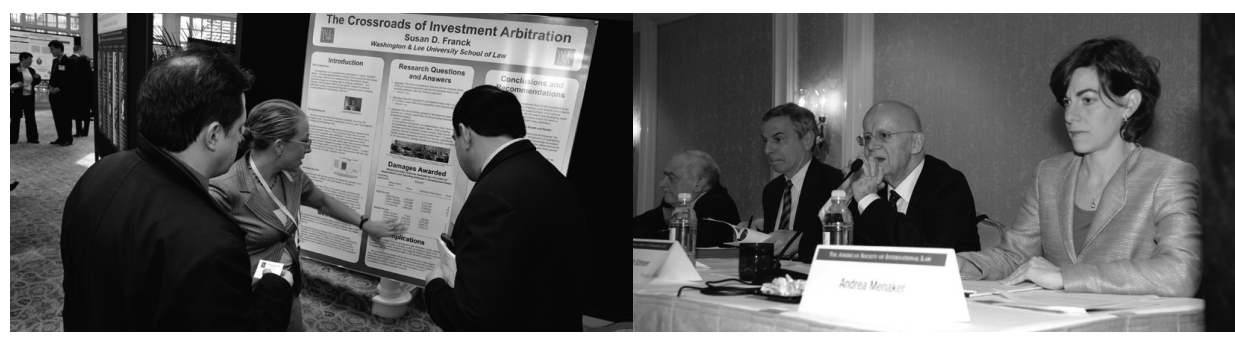

For more information about the Center and its upcoming programs, please contact Holtzmann Center Director Djurdja Lazic, dlazic@asil.org.

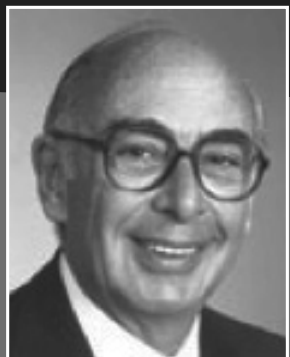

The ASIL Holtzmann Center is established in honor of Judge Howard M. Holtzmann. Over the course of his career, Judge Holtzmann has made enormous contributions to the field of international arbitration and conciliation, and mentored scores of young lawyers working in the field. He was central to the American Arbitration Association (AAA) work with the Arbitration Institute of the Stockholm Chamber of Commerce to build an East-

West bridge through international arbitration. Notable achievements include: service as a member of the U.S. delegation to the Arbitration Working Group of the UN Commission on International Trade Law (1974-2011), which produced the UNCITRAL Arbitration Rules, the UNCITRAL Conciliation Rules, and the UNCITRAL Model Law on International Commercial Arbitration, and service as a Member of the Iran-U.S. Claims Tribunal (1981-1994). For his pioneering work, the King of Sweden inducted Judge Holtzmann as a Commander of the Royal Order of the Polar Star in 2003. In 2005, he received the Silver Medal of Honor of Vienna, and in 2006, the AAA gave him its highest honor, the Peacemaker Award, for his "work to further peace throughout the world." Judge Holtzmann has been a member of ASIL since 1972 


\section{Debate, Discussion, and Problem Solving}
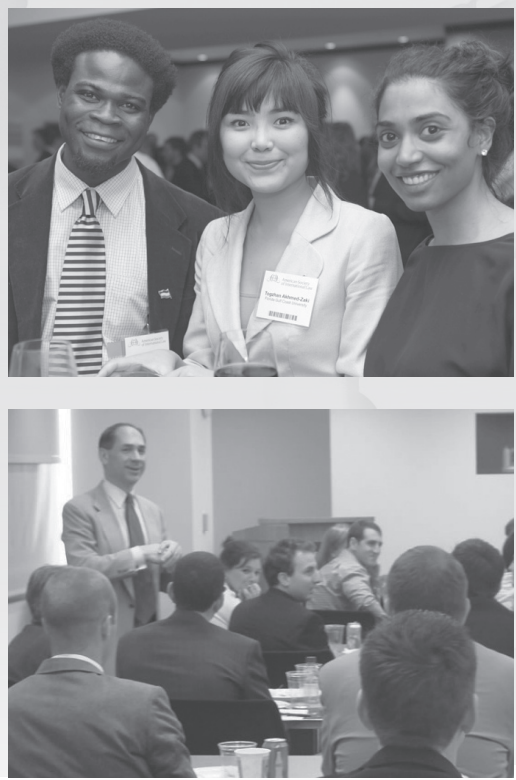

The Annual Meeting

is a bit like an overflowing buffet table of international law dishes. It brings people from all over the world, interesting topics, and is truly a defining event for international law aficionados.

Lucinda Low

Partner, Steptoe \& Johnson, LLP
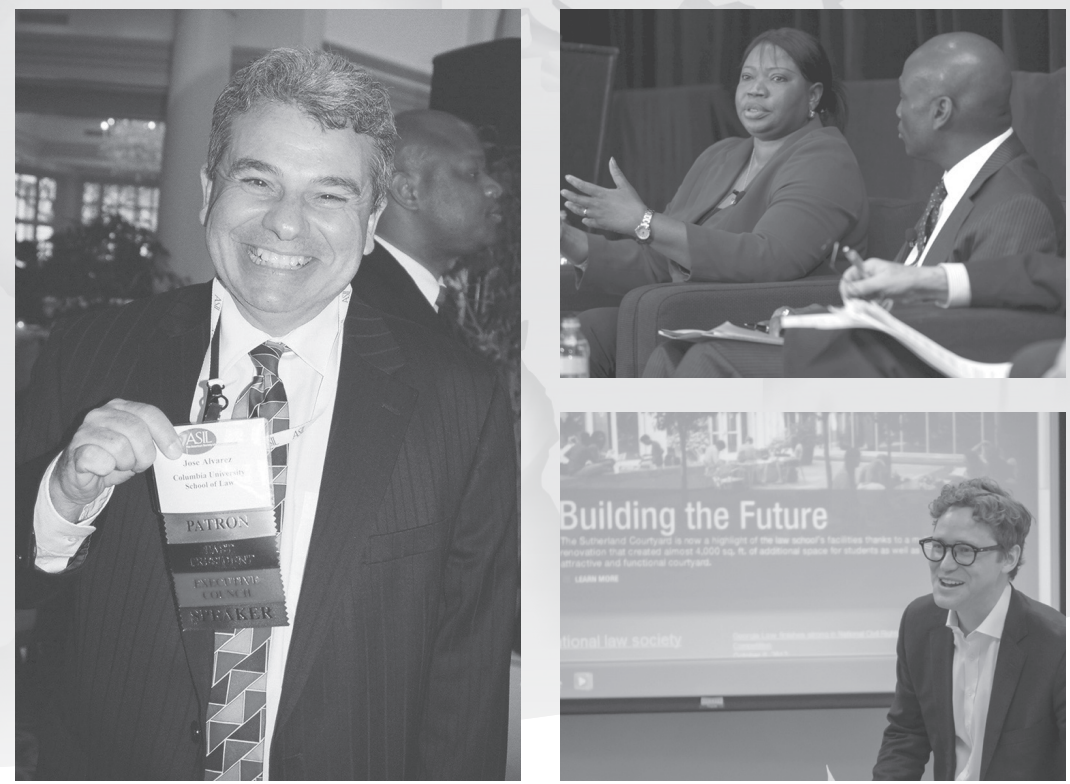

\section{ASIL 109TH ANNUAL MEETING}

APRIL 8 - 11, 2015 WASHINGTON, DC Save the Date!

With over a century of tradition and experience behind it, the American Society of International Law's Annual Meeting has become the most important gathering in the field of international law.

More than 1,200 practitioners, academics, and students travel to Washington, DC, each spring from all over the world to debate and discuss the latest developments in their field.

Visit www.asil.org/annualmeeting to learn more. ASIL member discounts apply.

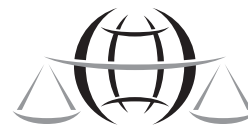

American Society of International Law

Serving International Lawyers.

Strengthening International Law. 


\section{Shape the Future of International Law}
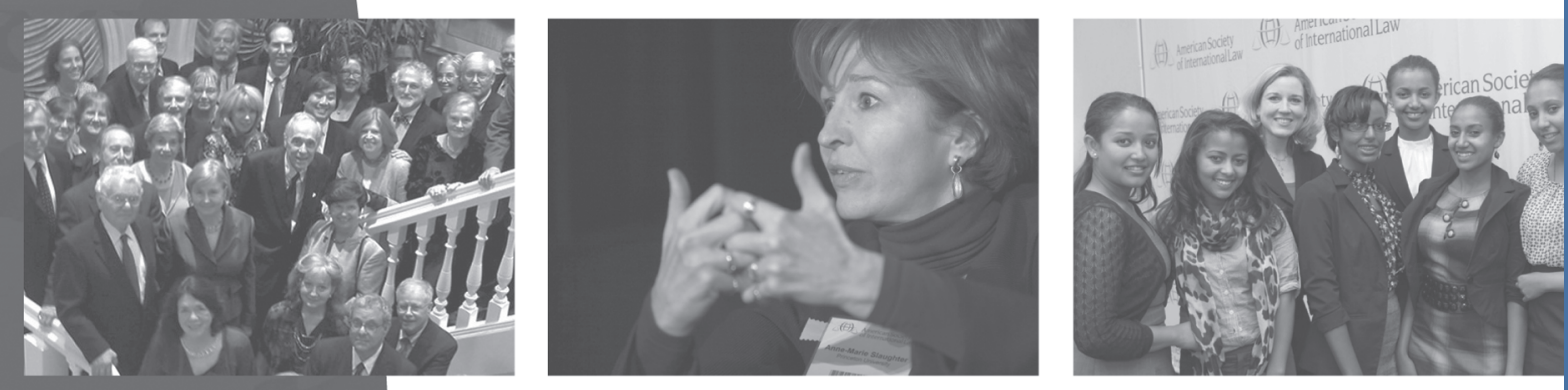

\section{JOIN ASIL}

ASIL has allowed
me to meet other
Iawyers with similar
interests, but also
exposed me to new
issues of international
law. ASIL offered me
a space to share my
ideas and build on
them...[and] to be an
active participant in
international law.
Chiara Giorgetti
Assistant Profiessor,
University of Richond
School of Law; formerly of
White \& Case LLP

The American Society of International Law is dedicated to fostering the study of international law and to promoting the establishment and maintenance of international relations on the basis of law and justice. Founded in 1906, it brings a 100-plus-year-old tradition of convening its diverse community, comprising nearly 4,000 members from more than 100 countries, to address the pressing international legal questions of the day. Its reputation for providing a forum for balanced, non-partisan, and rigorous analysis is unparalleled.

\section{Benefits of Membership}

- Scholarship and News

- Debate, Discussion, and Problem Solving

- Networking and Professional Development

- Education and Outreach

To take advantage of these and many other ASIL member benefits and to help shape the future of international law, join the world's leading association for scholars, practitioners, and students of international law.

Visit www.asil.org/membership to learn more and to join.

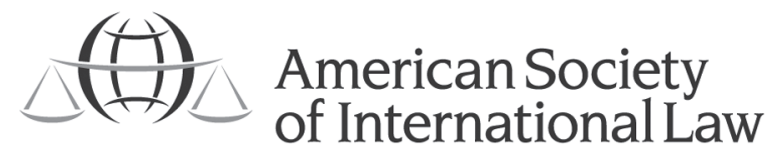

Serving International Lawyers.

Strengthening International Law.

2223 Massachusetts Avenue, NW | Washington, DC 20008 | www.asil.org 
